\title{
Competitive Position of Dependent Passenger Car Maintenance Companies - Influences, Developments and Challenges in the German Market
}

- Werdich Karl

\begin{abstract}
The presented paper concerns itself with passenger car maintenance companies and their competitiveness. Internal and external influences, change drivers and general changes in the companies and their organisation were identified and analysed. The influence of the development of technology and the diffusion of innovations are highlighted in particular. Under consideration of the competitiveness factors, current and future challenges for the passenger car maintenance companies were worked out. Based on these analyses, future tasks, problem statements and challenges were compiled for passenger car maintenance companies from which other subjects of scientific investigation in area of strategic and economic importance arose.
\end{abstract}

Keywords: Competition, Technological Change, Innovation, Skill Biased, After-Sales Service

JEL Classification: 033

\section{INTRODUCTION}

In the era of the vehicle networking and the assembling of mechanical and electronic components the car economy deals among other things with subjects like electric vehicles, carpooling, individual mobility and autonomous driving. A century ago the maintenance technician of the car was also its manufacturer who handcrafted vehicles with comparatively easy technology. In the meantime, this procedure has changed in a revolutionary way: Today the maintenance staff of cars looks for the smallest defective interchangeable electromechanical unity and the passenger car production evolved into high automated mass manufacturing.

The automobile industry in which 8.4 million people worldwide are occupied directly and for which more than 50 million people work indirectly (OICA, 2010), has changed different areas drastically. By way of illustration, the change of the car production would be stated from the individual manufacture of vehicles to the mass production in 1913 up to the worldwide propagation of lean production methods, which were developed in Japan, beginning in the 1980s till today (Womack, 1991). Already ten years later, car manufacturers worldwide were in position to offer a comparably high product quality within their vehicles as a basis service. As a result of this insufficient possibility of differentiation for the purchase decision of the costumer, the manufacturer itself focused increasingly on customer service quality since the middle of the 1990s (Rauner, 2002). According to Rauner, the vehicle sector in the States of the European Union not 
only plays a very important role for economic prosperity and employment, but also illustrates the important position of after-sales service of the passenger car maintenance companies (Rauner \& Spöttl, 1995). The vehicle trade comprises (in Germany) 460,000 employees, 38,500 vehicle companies and generated in 2013 a turnover of 139 billion euros. In the same year $61.5 \%$ of the gross yield on average were achieved in the after-sales business (ZDK, 2014a). Nevertheless, the supplier and offer structures depend on many factors of influence. The vehicle repair trade is influenced therefore by different change drivers like the car manufacturers, customers and the technology reform. Particularly the implemented innovations demanded by customers, manufacturers of vehicles and parts and partially by the legislator changed the passenger car maintenance companies in order to remain competitive to other market participants.

The present article deals with the identification and analysis of influences, change drivers and general changes on passenger car maintenance companies. The aim of this study is the representation of current and future challenges and the associated problems mainly brand passenger car maintenance companies are faced with. The investigation will be conducted under consideration of company competitiveness. Out of this, other investigation objects arise by which a knowledge profit for science in an area of economic and strategic importance is to be expected.

The article is organised after the introductory chapter as follows. Definition and organisation of the passenger car maintenance is explained in chapter 2. Section 3 shows the research design. Chapter 4 deals with the subject of influences and developments in the area of car manufacturers and passenger car maintenance companies. Section 5 indicates the challenges and problems to be accomplished by the passenger car maintenance companies. The last section provides conclusions and remarks.

\section{DEFINITION AND ORGANISATION OF PASSENGER CAR MAINTENANCE COMPANIES}

The maintenance ensures the functional safety and the serviceability of technical systems in general and of passenger cars in particular. It encloses all technical and administrative measures, as well as management measures during the life cycle of a unit. The maintenance serves for the preservation of functioning and operative condition or the return in this, so that it can fulfil the demanded function (DIN, 2003).

\subsection{Organisation of the Vehicle Trade Companies in the Association}

Similar to the organisations of the car manufacturers in the Czech Republic, in Germany and Europe (AIA, VDA, ACEA) the automobile trade is organised all over the Czech Republic and Germany and throughout Europe too. The participation on legislative topics is just as much a duty of the associations as the education and qualification of employees in the area of the vehicle trade. In the Czech Republic the vehicle repair trade is organised by the SAČR (Svaz prodejců a opravářru motorových vozidel České republiky - Czech Association for Motor Trades and Repair) and in Germany by the ZDK (Zentralverband Deutsches Kraftfahrzeuggewerbe - German Federation for Motor Trades and Repairs). Their interests are represented at European level by the CECRA (Conseil Européen du Commerce et de la Réparation - European Association of the Vehicle Trade) and based on their EU membership EU directives are valid. 
In both countries the relation between brand independent and dependent vehicle trade companies is roughly fifty-fifty (CECRA, 2013; Müller, 2008; ZDK, 2014) and there is a narrow contact and a close collaboration between the SAČR and the ZDK (SAČR, 2015).

\subsection{Organisation of the Vehicle Trade Companies with the Manufacturers}

In general two types of passenger car maintenance companies are to be distinguished. They differentiate themselves mutually through the contractual obligations to the manufacturers. Dependent passenger car maintenance companies characterise themselves by the existence of a direct interdependency (contract) to car manufacturers. The terms 'dependent', 'mark dependent', 'brand bound' and 'brand dependent' are used in this paper synonymously. In detail these car dealerships are as well as car workshops with several brands, car dealerships and car workshops with one brand, respectively. In this connection it is also often spoken of authorised workshops - which does not walk along, however, with the legal text because workshops may carry out servicing works without relation within the guarantee time too, as long as they keep the manufacturer's specifications. Independent passenger car maintenance companies in contrast do not have any contractual relationship with a car manufacturer. Both kinds of companies are organised in respective national associations. The brand dependent passenger car maintenance company is able to obtain all necessary maintenance resources and information (among other things spare parts, special tools, workshop installations and workshop information) directly from the respective car manufacturer or work tools and supplies are provided automatically to it before e.g. a new model is going to be launched. The maintenance companies are despite of brand connection authorised to acquire needed maintenance resources from the free market. The independent organisations can purchase also their needed maintenance resources from free market or directly from the specific car manufacturer, more precisely its distribution organisation. Nevertheless, this mostly does not take place directly by the car manufacturer, but by his authorised workshops or the associations and umbrella organisations (Dirlenbach, 2009; EU, 2010a; ZDK, 2011).

For example, the incorporated company Daimler AG arranged an entrance via data especially for independent maintenance companies and independent market partners. Through this access technical information about servicing and repair, service information and service literature, and an electronic part catalogue is available. In addition, the company guarantees through a system that knowledge and solutions of technical matters can be exchanged (DAI, 2012). The car manufacturer BMW for example offers independent maintenance companies which work together with one of many BMW service partners its paying online service system (Wenz, 2014). Similar resources of information and communication of other car manufacturers are readily available for passenger car maintenance companies.

\subsection{Organisation of the Vehicle Trade Companies in Relation to Service}

A company or an organisation disposes of resources which are essential to fulfil the demanded service. The differentiation between services of tangible or intangible nature shows that the employees affect the talents of the enterprise. While understanding tangible services, among other things, as machines, employees and software, intangible resources are licences, expert's knowledge, enterprise culture and relations. 
An analysis from 2002 about the change of the problems and the qualification requirements in the vehicle service sector shows a fundamental innovation of the qualification profile in the last two decades. The general orientation for modern professional work within the vehicle sector is therefore the automotive mechatronics with their ability to understand the technique and the business processes. Thus, the allocation of duties on the employees in vehicle workshops is not conducted anymore on basis of aggregates or parts, instead of this the working duties (problem solving, repair, service, etc.) take centre stage (Rauner, 2002). The change of tasks requires from the passenger car maintenance companies a high ability to innovate, which can be reached by a sustainable and modern training and qualification concept (Rauner \& Spöttl, 1995; Rauner, 2002).

\section{METHODOLOGY}

The paper focuses on the identification and analysis of competitiveness factors for firms' longterm profitability, which leads to current and future challenges of dependent passenger car maintenance companies.

The claim to a high transparency of the research process requires a systematic-structured research process. In figure 1 the several steps of research procedure are shown. To analyse the internal and external problems, research mainly consists of secondary data material and literature. Expert interviews are used to close data gaps to create current values and careful future assumptions.

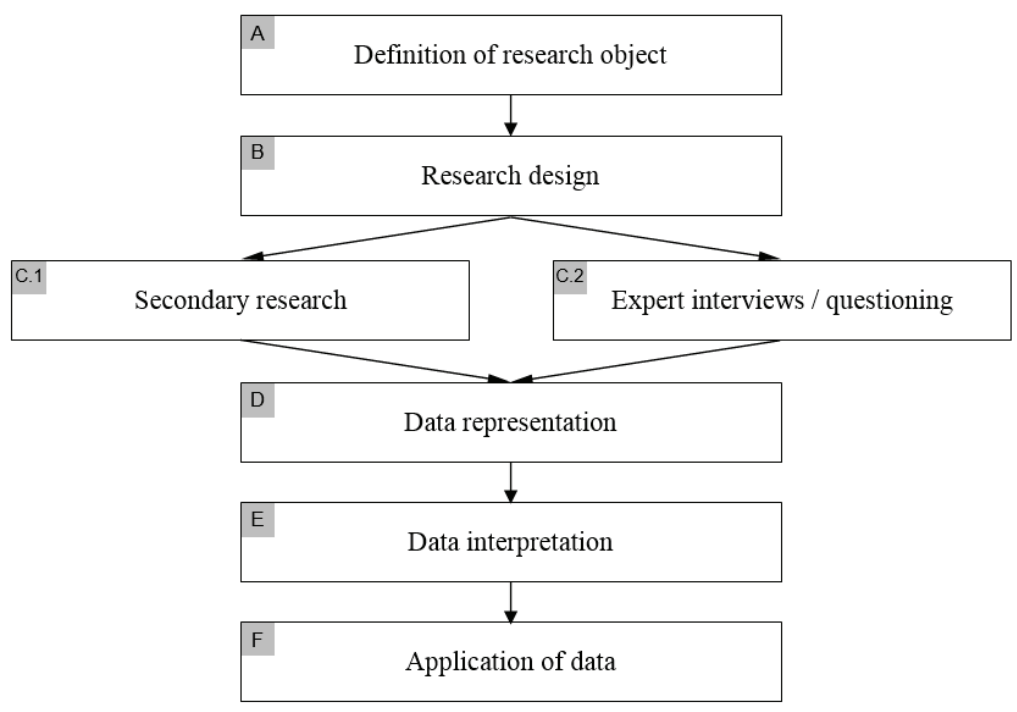

Fig. 1 - Systematic-structured research process. Source: Own representation based on (Atteslander, 2008) 
The study was used to discover new relationships between the different influences on the passenger car maintenance companies and to use the findings of this study to show up further need for research.

According to Porter's Five Forces Model (Porter, 2004), five competitive forces determine industry profitability. These are: the rivalry among existing firms, threat of new entrants, threat of substitute products or services, bargaining power of buyers and the bargaining power of suppliers. The investigation takes place under consideration of these five forces from market view. This approach is complemented with a resource-based consideration of the human and physical capital.

\section{INFLUENCES AND DEVELOPMENTS IN AUTOMOTIVE BUSINESS}

The illustration and the analysis of influences on passenger car maintenance companies and of general developments in automotive business is the purpose of this section.

The market-based consideration of the automotive business and the market participants drew a comprehensive picture about the influences and the developments. The itemisation of the change drivers and the structuring of the identified developments enabled the author to look at the subject from different points of view.

\subsection{Influence of the General Environment}

The vehicle trade is decisively constrained by the specifications of the car manufacturers. Maintenance companies have to face the following challenges: New vehicles with shorter developing cycles reach the market with a higher model variety, the manufacturers extend the so-called service intervals (after-sales service intervals), and a better customer focus by the passenger car maintenance companies is required. However, this developments demand an adapted qualification of the employees (Autozeitung, 2012; Jühling, 2009, Rauner, 2002).

The competition among the players in this market is high and will be rising through intermediaries like repair exchanges and workshop chains. The major threat to the new entrants is the initial investment - mainly in employee training and maintenance equipment to keep pace with the developments of car manufacturer. Threat of substitute products and services become bigger after guarantee phase of car manufacturer, because of cost advantages of the independent passenger car maintenance companies. Government regulations strengthen the independent maintenance companies by market and information access and the buyers or car owners in e.g. freedom of choice. Threat of forward integration of car manufacturer and of focussed segment strategies of part manufacturer and supplier.

The supply and offer structure in the maintenance area depends on many factors of influence. In figure 2 the change drivers, which were identified during the secondary research with influence on the vehicle trade, are shown and explained: 


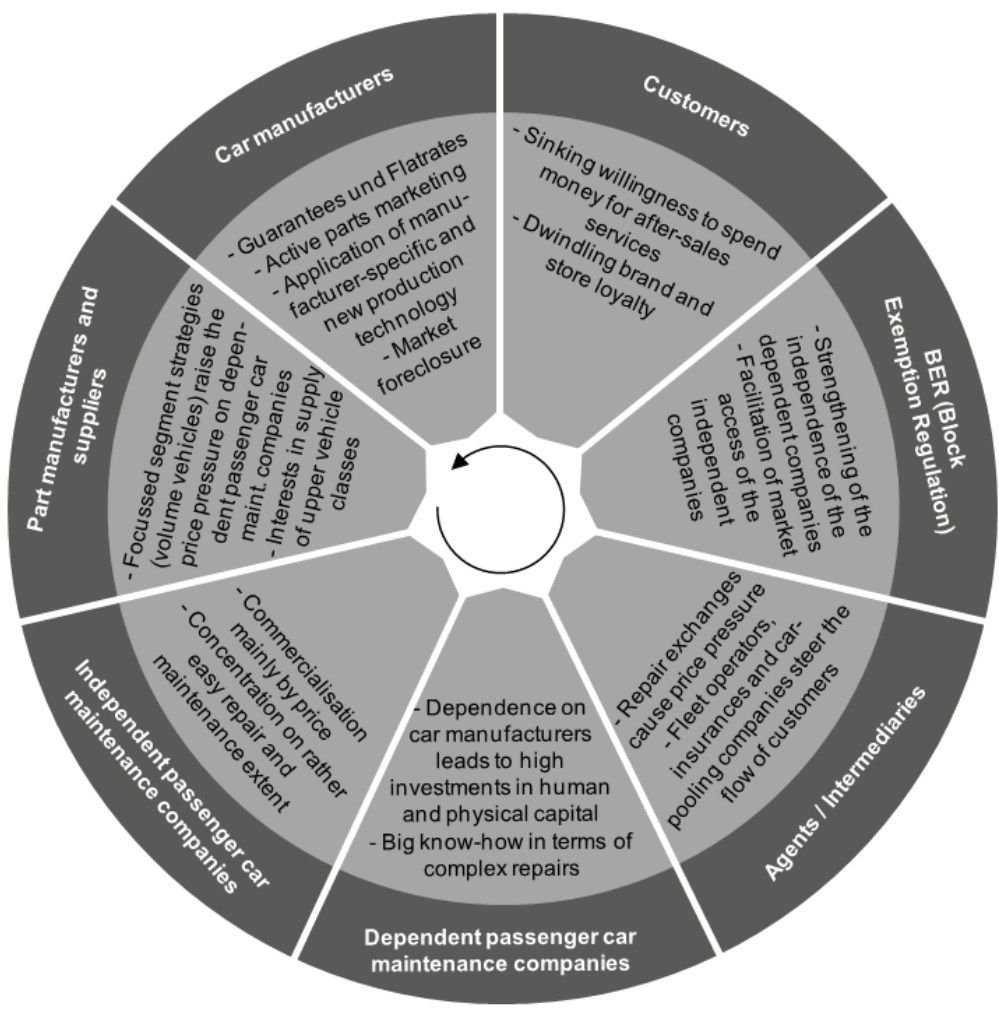

Fig. 2 - Change drivers and influences on the vehicle trade. Source: Own study based on (Bundesverband Carsharing, 2014; DAT, 2014; EU, 2010a; EU, 2010b; IFA, 2013; Rauner, 1995; VDA, 2013; ZDK, 2014a)

In addition, the varied general conditions of changes in the vehicle trade are jointly responsible. Especially new technologies (see DAT, 2014; VDA, 2013) initiate changes.

\subsection{Influence of Car Manufacturers Developments}

Through the contractual obligations the respective car manufacturers have a lot of influence on the planning and principles of operation of dependent passenger car maintenance companies. Technological changes of the products affect not only the mode of operation and the associated investment in employee's qualification, but cause an increase of capital assets (in particular electronic maintenance equipment) by specifications of the car manufacturers.

The developments in the maintenance area are effected by many influences of car manufacturer. In figure 3 a selection of the most important identified effects are shown and further explained in the following text passages: 


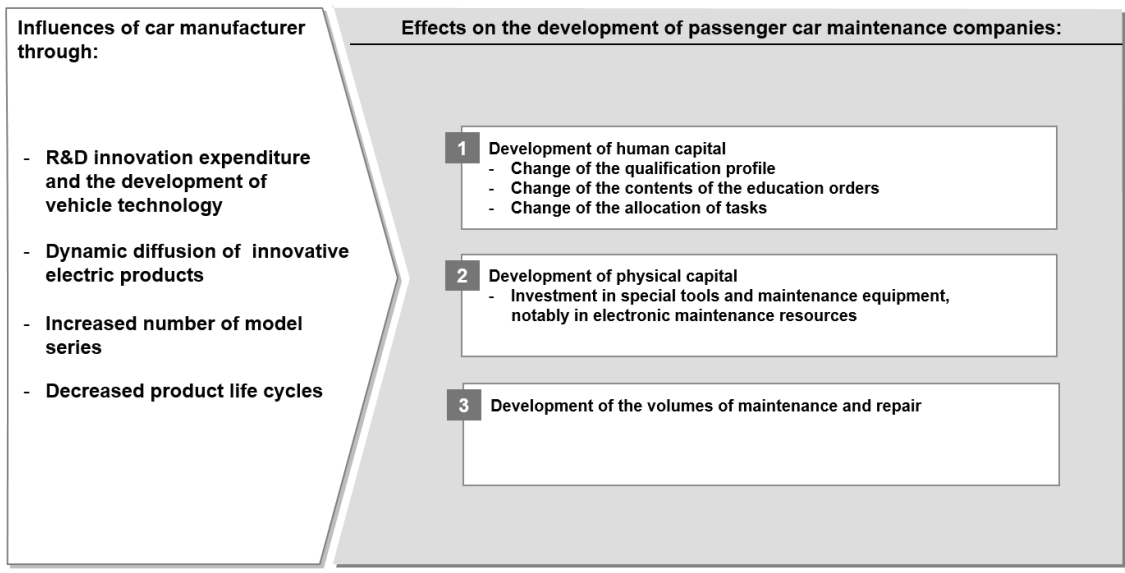

Fig. 3 - Influences of the car manufacturer and resulting effect. Source: Own representation based on (Dombrowski and Engel, 2014; Dudenböffer, 2012; Forster, 2013; Jübling, 2009; ZDK, 2014a; Rübrmaier, 2014; ZEW, 2014; ZVEI, 2014)

\section{R\&D innovation expenditure and the development of vehicle technology}

The vehicle manufacturing has for several years the highest innovation intensity in the processing trade (ZEW, Vol. 2012-2014). With a proportion of $10.2 \%$ of the turnover in 2012 the innovation expenses are as high as in no other sector. For the years 2013 and 2014 an increase of the innovation expenses is expected on 45.4 and 47.1 billion euros. Relating to the sub sector automobile manufacturing the figures for the years from 2009 to 2012 are as follows: $9.8 \%$ in $2009,9.1 \%$ in $2010,9.3 \%$ in 2011 and $10.3 \%$ in 2012 (ZEW, 2014).

The propagation of electronic components and semiconductor components has reached a portion of approx. $35-40 \%$ on the production value. This represents a tenfold increase in the period from 1985 to 2010 (Elektronikpraxis, 2008; Handelsblatt, 2010). A portion of approx. 90 percent of the innovations are in the area of car electronic and this leads to the steadily growing share of electronic and electromechanical components within car (Schweikle, 2009).

Schmutzler (2012) speaks of 70 control units, which in vehicles of the upper middle class are obstructed. Abelein and Lochner (2012) number the control units on up to 100 with more than 7,000 semiconductor components and they emphasise that this number will increase drastically by crossover from conventional vehicle to electric car.

The generation change from vehicle with combustion engine to electric car is illustrated in figure 4 in the dynamic diffusion of electronic products. For the lower curve (car with combustion engine) previous and current values are taken and for future the values are extended mathematically. In electric cars (upper curve) this value of electronic and semiconductor components are even higher, because the introduction of the electric drive unit require the change and omission of conventional parts. 


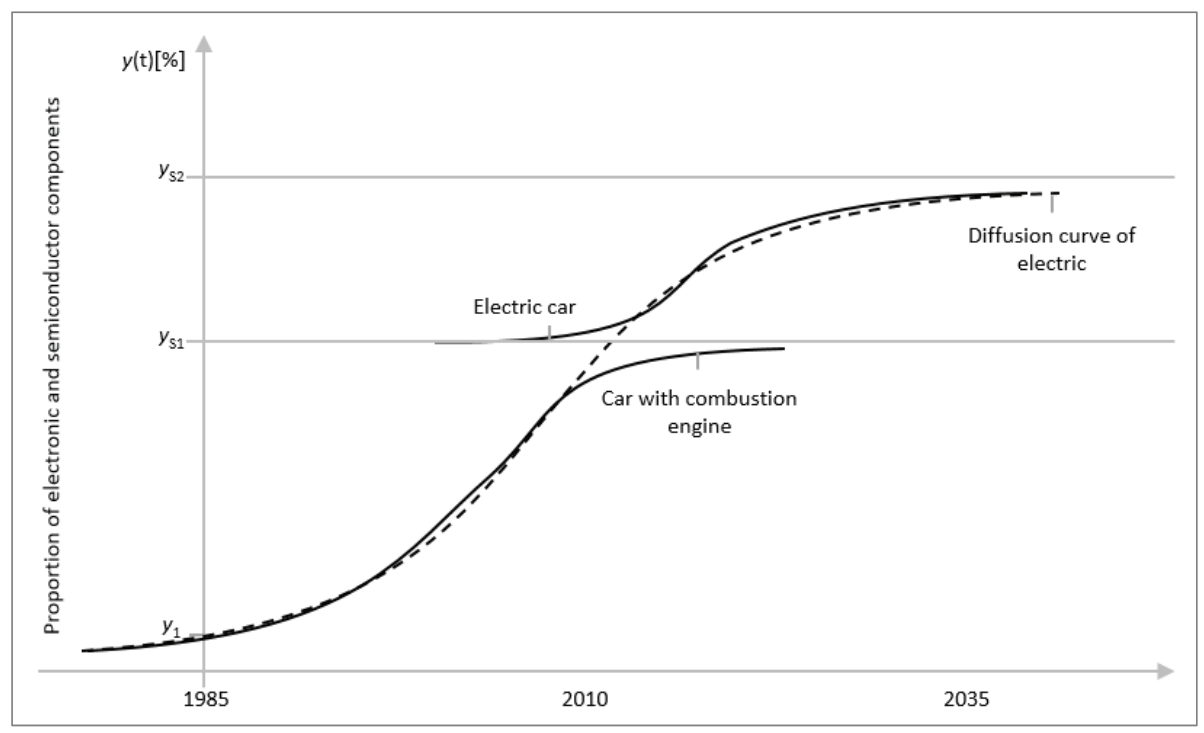

Fig. 4 - Dynamic diffusion of the innovations of electronic products. Source: Own representation based on (Elektronikpraxis, 2008; Forster, 2013; Handelsblatt, 2010; Schweikle, 2009; ZVEI, 2014b)

The S-shaped diffusion of innovations is to be found in many empiric analyses of innovation propagation. In addition it can be assumed that diffusion functions of innovations of successive product generations have a general functional curve (diffusion curve of electric) which superpose the separate curves (Nefidow \& Nefiodow, 2014; Oppitz, 2014). For the diffusion curve of electric car the author decided to use S-shaped diffusion too.

The value percentage of electronic and microelectronic or semiconductor elements per automobile increases worldwide and an end of this trend is not expected for the next ten years (ZVEI, 2013; ZVEI, 2014a).

An investigation of CAR (Center Automotive Research) at the university of Duisburg-Essen demonstrated that the number of the pure model series (e.g. Opel Astra) increased from 227 in 1995 to 376 in 2011. This corresponds to a growth rate of more than 65 per cent in the same time period. Forecasts state that the number of model series will increase to 415 by 2015 (Dudenhöffer, 2012). Product life cycles in the 70s were on average eight years, this period decreased nowadays to three till four years (Jühling, 2009; Scheimann, 2011).

The increased expenditure for innovations point out that further technical innovations are expected for future years. This innovations have to be managed after the market launch by the maintenance companies too.

\section{Development of passenger car maintenance companies' human capital}

Due to the current demands, the new job profile of the automotive mechatronics was brought into force officially on 1st August 2003 and substituted the former job profile of the vehicle mechanic from the 10th March of 1989 (BGBL, 2003). In the meantime the trade of vehicle 
mechanics and car electricians craft was formally united on the 1st April 1998 (Rauner, 2002).

In figure 5 the development of the apprenticeships in the German automobile trade is shown. For reasons of easier readability, gender-specific differentiations are omitted. Corresponding terms or professional titles are valid for both genders in terms of the General Equal Treatment Act.

\section{$\begin{array}{lllllllllllll}1934 & 1950 & 1953 & 1957 & 1978 & 1981 & 1989 & 1998 & 2003 & 2004 & 2009 & 2013 & 2014\end{array}$}

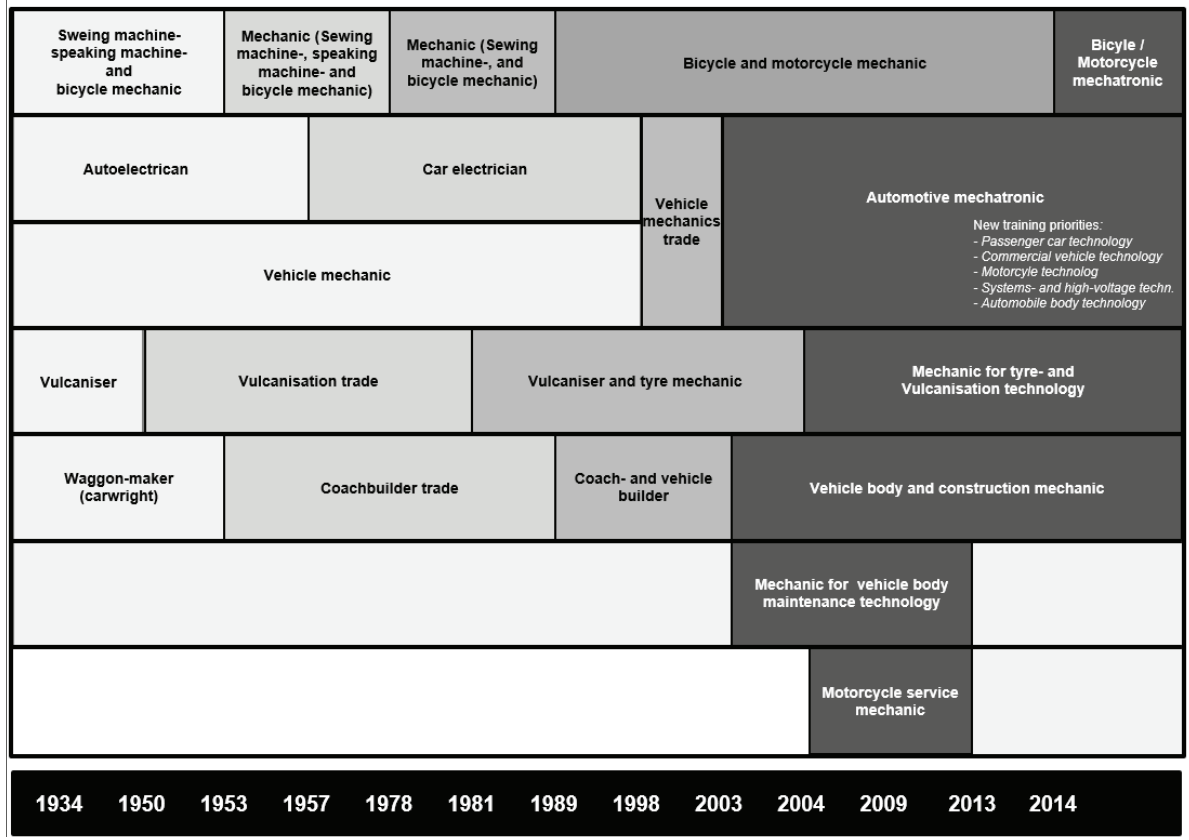

Fig. 5 - Development of apprenticeships in the German automobile trade. Source: Own study based on (Banner, 2010; BGBL, 2013; BGBL, 2014; Gewande, 2007)

The education regulation for the automobile mechatronics were adapted once again in 2013 in order to meet the increased requirements in diagnosis knowledge, the rising portion in obstructed mechatronic systems and the interlinking of the vehicles by information and communication systems in modern vehicles. An integrated high-voltage apprenticeship shows the rising need in high-voltage system knowledge which is used, for example, on electric vehicles (BGBL, 2013; Syha, 2013). Well-educated labour force is an important competitive factor for passenger car maintenance companies. The training possibilities within dependent passenger car maintenance companies are very good, in workshop chains good and in independent workshops medium to poor (Dombrowski \& Engel, 2014).

The shift of tasks changed the necessary qualification profile of the maintenance employees. The movement of the proportion in diagnosis tasks caused a change of training content. Figure 6 shows the reallocation of the main priorities over time. 


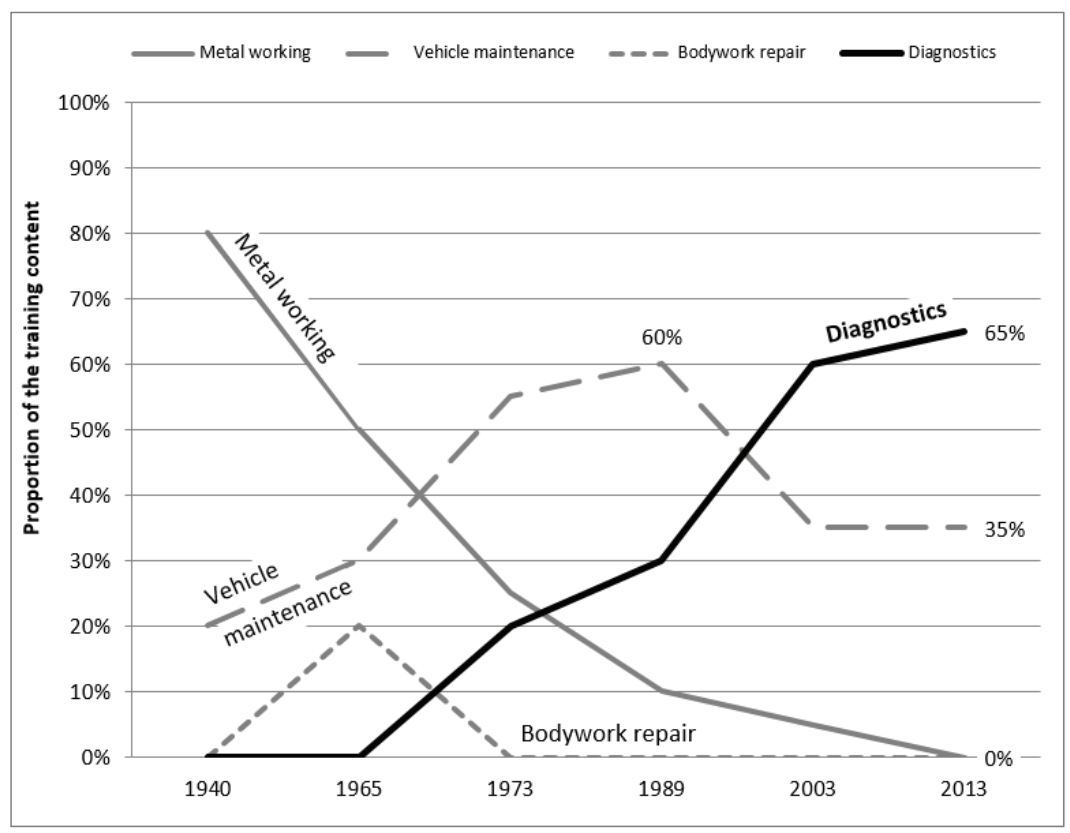

Fig. 6 - Comparison of the contents of the education orders from 1940 to 2013. Own study based on (BGBL, 2013; Lingnau, 2009; Syha, 2013; ZDK, 2014b)

The allocation of tasks in the maintenance companies moved due to the further rising share of the electronics components and semiconductor components in the vehicle already in 2002 to 52 per cent of the working hours. (Rauner, 2002) Today the portion is estimated at roughly 65 per cent.

Besides, this trend affects the physical capital of the passenger car maintenance companies, because the additional special tools and electronic workshop equipment must be procured.

\section{Development of passenger car maintenance companies' physical capital}

New technologies and vehicle models require usually new special tools and workshop equipment and investments in maintenance resources.

For example, the technical development of new driver assistant systems requires a suitable adaptation of the maintenance companies and with it investments in the workshop equipment of more than 5,000 euros (Baeuchle, 2014).

Nevertheless, the car manufacturer plan and develop not only components, but new concepts of drive technology are in the strategic focus of the development and marketing departments - these are hybrid vehicles with different technical characteristic, battery-operated electric vehicles and fuel cell supported electric vehicles (Schade, 2014)

For many passenger car maintenance companies the repair of electric vehicles is a new field of activity for which they must prepare. Besides the training of the maintenance employees in the 
area of high-voltage, the assemblies of the electric motors, control units, and energy storages new utilities for the maintenance of the vehicles have to be purchased.

Passenger car maintenance companies have to prepare them early for the new tasks in the area of electric vehicles. In spite of the relatively low number of 11,295 admitted electric cars in Germany to the end of the year 2013, recommend the minister of the national guild Wilhelm Hülsdonk and the autoexpert Willi Diez to carry out the training of employees and the equipment of the companies in a contemporary way. According to Diez, a passenger car maintenance company must invest about 21,000 euros for the equipment and employees trainings (Rührmair, 2014). Nevertheless, the investment amounts can increase even further, if the respective car manufacturer confront the dependent passenger car maintenance companies with enlarged requirements.

The financial situation within dependent passenger car maintenance companies is very good, in workshop chains good and in independent workshops medium to poor (Dombrowski \& Engel, 2014).

According to Karpinski (ZDK, 2015) the market is fought hard and the average yield is low. After 1.3 percent in 2013 expects the German Federation for Motor Trades and Repairs for 2014 an average yield between 1.0 and 1.2 percent, which is too low for the increased requirements of car manufacturer.

The author sees the reduced average yield combined with the general financial situation of specific workshop types critical and states that this will lead to further change the market.

\section{Development of maintenance and repair volumes}

A German institute in the area of automotive business (IFA, 2013) has identified as essential causes for the decreasing maintenance and repair expenditure the increasing vehicle and components quality, the declining mileage of the admitted passenger cars and the limited growth by passenger car registration.

This fact could further intensify with increasing number of electric vehicles. The University of Applied Sciences Nürtingen-Geislingen has carried out an investigation for comparison of workshop costs. For the comparison different small cars with an age of eight years and a mileage of yearly 8,000 kilometres are used. The calculated costs of 2,350 euros for the repair and maintenance for electric vehicles are faced with 3,650 euros of cars with internal combustion engine (Diez \& Burkert, 2014).

\section{Summary of the developments}

Market changes and the diffusion of innovations have influence on the development of the passenger car maintenance companies. On the basis of the changes of the car manufacturers and the passenger car maintenance companies over time development principles can be derived by analysis of the diffusion functions. To analyse the interrelationships scientifically could contribute to the conclusion of strategic objectives for the management of passenger car maintenance companies. 
The common consideration of changes introduced by market participants like car manufacturers were restricted, as well as the common consideration of how the passenger car maintenance companies reacted to those changes in detail. A complementary study, by means of fieldwork in case study design, would have drawn an even more exact picture how and how fast the passenger car maintenance companies react to changes and influences in particular. For further studies the topic should be more limited and deeper and a focus on some dependent passenger car maintenance companies by case studies is suggested.

Developing principles in time series of the development of electronic maintenance equipment inventories would deliver academically valuable results regarding the reaction of the passenger car maintenance companies on market changes.

\section{PROBLEMS AND CHALLENGES FOR THE PASSENGER CAR MAINTENANCE COMPANIES}

The changes in automobile manufacturing and in the maintenance sector and the change in the customer behaviour lead to problem statements and with it to challenges for the passenger car maintenance companies.

While vehicles with an age of less than two years are repaired in $97 \%$ of cases by dependent passenger car maintenance companies, this rate drops with increasing age of the vehicles to a value of $28 \%$ for vehicles of ten and more years (DAT, 2014). Dependent passenger car maintenance companies take the pioneer role for new product launches in the maintenance process and they are the first one who are confronted with new technologies.

\subsection{Problems Passenger Car Maintenance Companies are Faced with}

The focus of the car manufacturers is to generate an attractive product offer for customer, but they often neglect at the same time to consider the support of the product. The 38,500 vehicle maintenance companies in Germany deal with the maintenance, inspection, repair and improvement (of weak points) of the vehicle population of about 43.9 million passenger cars (KBA, 2014), which are faced with a continuous wear-off.

The demonstrated changes from chapter 4 lead to problem statements of the passenger car maintenance companies:

a) A steadily growing proportion of electronics and semiconductor parts and a change of workshop orders (movement of the portion of the repair to diagnosis and preventive maintenance) lead to the fact that investments for modernisation and training are rising steadily.

b) A declining volume of employment characterise the future market of the passenger car maintenance - forecasts predict a reduction from up to 100,000 jobs till 2025 (Weimer, 2006). According to calculations of the institute IFA (2013) between 50,000 and 71,000 jobs in the area of maintenance companies and car dealers are threatened. Between the years 2000 and 2013 already 73,000 places are being reduced in this sector. This employment trend will imply deep cutbacks in the vehicle trade. 
c) The rising maintenance intervals and the improved quality of the vehicles, the reduced mileage of passenger cars and the limited growth in new passenger car registration imply less maintenance work per vehicle and year. According to a forecast (IFA, 2013) the number of the sold wage hours will lie in 2020 between 11 and 15 percent under the today's level - for 2025 even a reduction of about 17 percent is to be calculated.

d) The raised competitive intensity by new company types and suppliers (in particular workshop chains) causes that the number of the companies decreases or the market volume is redistributed. The loyalty to the company of the vehicle purchase decreases with growing vehicle age too.

\subsection{Challenges for Passenger Car Maintenance Companies}

In this chapter, after a short explanation of the used theoretical approaches and the definition of strategy, further results of the study are presented. Considering the subdivision in market influence and the internal organisation (cf. chapter 2.2 and 2.3), changes and thus general challenges were recorded and suitable categories were assigned.

The market-based view focuses on the external environment of the company. Market entry barriers try to keep away competitors from the market. This approach assumes that the company success is significantly influenced by the competitive position. The resource-based view is an approach that examines the internal conditions of an organisation under which existing resources can become a strategic competitive advantage.

The main objective of a sustained company is to protect the long-term survivability (Rollberg, 2001). Strategy is the art and science to develop and use all forces of an enterprise in such a way, that the long-term survival is protected (Simon, 2003).

Enclosed please find the important identified changes and with it the challenges for the preservation of the competitiveness of passenger car maintenance companies (see BGBL, 2013; BMBF, 2013, Braess \& Seiffert, 2013; Bundesverband Carsharing, 2014; DAT, 2014; Diez, 2012; IFA, 2013; KFZ Wirtschaft, 2013; Merkel, 2013; Neubauer \& Rudow, 2012; Peitsmeier, 2008; Weimer, 2006; ZDK, 2011):

I) Technology

- Share of electronics grows and with it the portion in diagnosis;

- Start of e-mobility and high voltage apprenticeship (also data stream);

- Rising complexity of the vehicles;

- New technologies: wheel-hub drive, fuel cells, electrical suspension, autonomous driving;

- New technologies and production methods increase the costs and the prices in after-sales business, amongst others, through investments; cost disadvantages but also competitive advantage for dependent passenger car maintenance companies (market foreclosure). 
II) Customer

- Changed customer behaviour;

- New mobility thinking;

- Car-pooling.

III) Structure of the market

- Trend towards multi-brand after-sales service;

- Workshop concepts for independent passenger car maintenance companies expand and register a market success;

- Repair exchanges ignite a price war;

- New workshop types;

- Competition and pricing pressure through workshop chains (increasing pricing pressure through workshop chains like Bosch, A.T.U., Vergölst and 1a Autoservice).

IV) Structure of the passenger car maintenance companies

- Changes for the employees (amongst others, more flexible working time and qualification skills);

- Trend towards complete offers;

- Professionalisation of the dependent passenger car maintenance companies (increased requirements of the car manufacturer);

- Trend towards specialisation.

The shifting of tasks to diagnostics affects the capitalisation of the passenger car maintenance companies because a greater amount of special tools and electronic workshop equipment must be procured. The diffusion of mechatronic systems also changed the education of the maintenance employees. In summary, the change of the problems arises primarily by the quantitative internal changes in the main fields of activity: Mechanics, inspection and maintenance, electrics/ electronics and car body works. Especially the technologically changed electromechanical systems in the automobile cause that the workshop equipment and the education particularly the qualification of the employees is continuously developed.

The literature pays too little attention on how the diffusion of product innovations of car manufacturers and the reaction of the passenger car maintenance companies and the accompanied expenditures for modernisation correlate.

\section{CONCLUSION}

The companies' competitiveness is becoming very important today. Especially in a hard fought market like the passenger car maintenance business the competitiveness of companies is an important factor to secure the survival. For this, it is tremendously important to develop and use 
all forces of an enterprise. The carried out investigation explains the influence working on the market participants and challenges.

The aim of this article was the identification and analysis of influences on passenger car maintenance companies and the presentation of the current and future challenges and the problems walking along with it for dependent passenger car maintenance companies, under the aspect of the competitiveness.

\section{Main results are:}

- Identification of market influences divided according to change drivers;

- Detailed representation of the influences of car manufacturer and their effect on the maintenance companies;

- Demonstration of the interrelation between innovation expenditures and share of electronic components (diffusion curves) and the increased amount of diagnosis tasks;

- Representation of the evolutions of human and physical capital in the maintenance firms;

- Showing of changes in maintenance and repair volumes caused by generation change from conventional combustion engine to electric car;

- Identification and representation of current and future problems and the subsequent challenges in the area of technology, customer, structure of the market and of the passenger car maintenance companies itself.

Finally it can be stated, that the carried out investigation offers a good overview about the subject. Influences and effects on the passenger car maintenance companies could be registered, categorised and analysed. Besides, it could be concluded that developments of dependent passenger car maintenance companies should be examined by a complementary quantitative investigation, which will leads to further new scientific knowledge.

\section{References}

1. Abelein, U., Lochner, H., Hahn, D., \& Straube, S. (2012, March). Complexity, quality and robustness-the challenges of tomorrow's automotive electronics. In Design, Automation \& Test in Europe Conference \& Exbibition (DATE), 2012 (pp. 870-871). IEEE. http://dx.doi. org/10.1109/DATE.2012.6176573

2. Atteslander, P. (2008). Methoden der empirischen Sozialforschung. Berlin: Erich Schmidt Verlag $\mathrm{GmbH} \& \mathrm{Co}$.

3. Autozeitung. (2012). Service Intervalle 2012 Vergleich Top Flop Rangliste. Hamburg: Bauer Digital. Retrieved October 30, 2014, from http://www.autozeitung.de/ rat-tat/ serviceintervalle-2012-vergleich-top-flop-rangliste?page $=0,3$

4. Baeuchle, C. (2014). VW rudert bei Service-Standards zurück - Hobe Investitionen in diverse Arbeitsplätze notwendig. Würzburg: Vogel Business Media. Retrieved December 29, 2014, from http://www.kfz-betrieb.vogel.de/service/management/articles/461431/ 
5. Banner, G., Küster Simic, A., \& Gül, O. (2010). Kraftfahrzenghandwerk 2010 - Eine Branche im Wandel. Frankfurt a. M.: IG Metall. Retrieved December 29, 2014, from http://www. igmetall.de/internet/0158132_Branchenreport_Kfz_Handwerk_769c3009871949a044c61d 765281ededcd10d19b.pdf

6. BGBL. (2003). Verordnung über die Berufsausbildung zum Kraftfahrzeng-mechaniker/zur Kraftfahrzeu gmechanikerin). Bundesgesetzblatt Jahrgang 2003 Teil I Nr. 34. Köln: Bundesanzeiger Verlag. Retrieved July 16, 2013.

7. BGBL. (2013). Verordnung über die Berufsausbildung zum Kraftfahrzeng-mechatroniker und zur Kraftf ahrzeugmechatronikerin. Bundesgesetzblatt Jahrgang 2013 Teil I Nr. 29. Köln: Bundesanzeiger Verlag. Retrieved June 20, 2013.

8. BGBL. (2014). Verordnung über die Berufsausbildung zum Kraftfahrzeug ᄀmechatroniker und zur Kraft fahržeugmechatronikerin. Bundesgesetzblatt Jahrgang 2014 Teil I Nr. 25. Köln: Bundesanzeiger Verlag. Retrieved June 20, 2014.

9. BMBF. (2013). Elektromobilität - das Auto neu denken. Bonn: Bundesministerium für Bildung und Forschung.

10. Braess, H. H., \& Seiffert, U. (2013). Vieweg-Handbuch Kraftfahrzengtechnik. Wiesbaden: Springer Vieweg.

11. Bundesverband Carsharing. (2014). Jahresbericht 2013. Berlin: Bundesverband Carsharing.

12. CECRA. (2013). CECR A auf europäischer Ebene. Brüssel: CECRA. Retrieved October 29, 2014, from http://www.cecra.eu/page/de

13. DAI. (2012). Mercedes-Benz Werkstatt Informationen. Stuttgart: Daimler AG. Retrieved October 29, 2014, from http://www.mercedes-benz.de/content/germany/mpc/mpc_germany_ website/de/home_mpc/van/home/services_accessories/services_and_workshop/ workshop-information.html

14. DAT. (2014). 2014 DAT Report. Würzburg: Vogel Business Media.

15. Diez, W. (2012). Grundlagen der Automobilwirtschaft. München: Auto-Business-Verlag.

16. Diez, W., \& Burkert, A. (2014). Elektromobilität und die Folgen für den Standort D. ATZ - Automobiltechnische Zeitschrift, 116 (11), 30-35. http://dx.doi.org/10.1007/s35148-014-2011-9

17. DIN. (2003). DIN 31051:2003-6. Grundlagen der Instandhaltung. Berlin, Beuth Verlag.

18. Dirlenbach, H. (2009). Erfolgreiches Management von After-sales-Service-Innovationen in der Automobilindustrie. Eine Mixed-methods-Analyse. Aachen: Shaker.

19. Dombrowski, U., \& Engel, C. (2014). Impact of Electric Mobility on the After Sales Service in the Automotive Industry. Procedia CIRP 16, 152-157. http://dx.doi.org/10.1016/ j.procir.2014.01.022

20. Dudenhöffer, F. (2012). Studie - Modellvielfalt bei Autoherstellern explodiert. München: FOCUS Online. Retrieved December 29, 2014, from http://www.focus.de/finanzen/news/ wirtschaftsticker/studie-modell vielfalt-bei-autoherstellern-explodiert_aid_752126.html 
21. Elektronikpraxis. (2008). SMT/Hybrid/Packaging 2008. Würzburg: Vogel Business Media. Retrieved December 29, 2014, from http://www.elektronikpraxis.vogel.de/ baugruppenfertigung/articles /122537/

22. European Commision (2010a). VERORDNUNG (EU) Nr. 461/2010 DER KOMMISSIO. Amtsblatt der Europäischen Union. L129/52 DE. Luxemburg: EU. Retrieved May 27, 2010.

23. European Commision (2010b). VERORDNUNG (EU) Nr. 330/2010 DER KOMMISSION. Amtsblatt der Europäischen Union. L102/1 DE. Luxemburg: EU. Retrieved April 20, 2010.

24. Forster, C., Zapp, M., Aelker, J., Westkämüer, E., \& Bauernhansl, T. (2013). Collaborative value chain management between automotive and semiconductor industry: an analysis of differences and improvement measures. Procedia CIRP 12, 312-317. http://dx.doi. org/10.1016/j.procir.2013.09.054

25. Gewande, W. D. (2007). Historische Entwicklung der staatlich anerkannten Aus-bildungsberufe im Handwerk und ibrer Ordnungsmittel von 1934 bis 2008. Berlin: Zentralverband des Deutschen Handwerks e. V. Retrieved December 29, 2014, from http://www.zdh.de/fileadmin/user_ upload/themen/Bildung/Ausbildungsordnungen/Gen_1934-2008__12_2007___Inhalt. pdf

26. Handelsblatt. (2010). Intelligentere Mobilität - Wie das Internet die Autos erobert. Düsseldorf: Handelsblatt GmbH. Retrieved December 29, 2014, from http://www.handelsblatt. com/auto/test-technik/intelligentere-mobilitaet-wie-das-internet-die-autos-erobert-seiteall/3656752-all.html

27. IFA. (2013). Studie Automobilservice 2025. Entwicklungslinien im Servicegeschäft der Zukunft. München: Springer Fachmedien.

28. Jühling, E., Torney, M., Herrmann, C. \& Dröder, K. (2009). Framework for the Integration of Service and Technology Strategies. CIRP IPS2 Conference 2009, 132-140. Cranfield: Cranfield University Press.

29. KBA. (2014). Jahresbilanz des Fahrzengbestandes am 1. Januar 2014. Flensburg: KraftfahrtBundesamt. Retrieved December 29, 2014, from http://www.kba.de/DE/ Statistik/ Fahrzeuge/Bestand/bestand_node.html

30. KFZ Wirtschaft. (2013). Die Strategie der Fast-Fitter. Wien: Österreichischer Wirtschaftsverlag. Retrieved October 30, 2014, from http://www.automotive. co.at/kfzwirtschaft/die-strategie-der-fast-fitter-2051

31. Lingnau, G. (2009). Die Chronik. 100 Jahre Deutsches Kraftfahrzenggewerbe. Bonn: Wirtschaftsgesellschaft des Kraftfahrzeuggewerbes mbH.

32. Merkel, A. (2013). Energiewende Mobilität. Leitmarket und Leitanbieter für Elektromobilität. Berlin: Presse - und Informationsamt der Bundesregierung. Retrieved Oktober 30, 2014, from http://www.bundesregierung.de/Webs/Breg/DE/Themen/Energiewende/Mobilitaet/ podcast/_node.html

33. Müller, K. (2008). EU-Osterweiterung - Erste Zwischenbilanz für das Handwerk. Duderstadt: Mecke. 
34. Nefiodow, L.A., \& Nefiodow, S. (2014). Der sechste Kondratieff. Die neue lange Welle der Weltwirtschaft; die langen Wellen der weltwirtschaftlichen Entwicklung. Sankt Augustin: Rhein-SiegVerl.

35. Neubauer, W., \& Rudow, B. (2012). Trends in der Automobilindustrie: Entwicklungstendenzen - Betriebsratsarbeit - Stener- und Fördertechnik - Gießereitechnik - Informationstechnologie und -systeme. München: Oldenbourg.

36. OICA. (2010). Auto Jobs. Paris: OICA. Retrieved December 29, 2014, from http://www.oica. net/category/economic-contributions/auto-jobs/

37. Oppitz, V. (2014). Diffusionsmodelle der Produktinnovation. Forschungsbeiträge der Naturwissenschaftlichen Klasse, 97-126. München: Sudetendt. Akad. der Wissenschaften und Künste.

38. Peitsmeier, H. (2008). Autowerkstätten - Schnelles Geld mit alten Autos. Frankfurt am Main: Frankfurter Allgemeine Zeitung. Retrieved October 29, 2014, from http://www.faz.net/ aktuell/wirtschaft/autowerkstaetten-schnelles-geld-mit-alten-autos-1114619 .html

39. Porter, M.E. (2004). Competitive advantage: creating and sustaining superior performance. New York: Free Press.

40. Rauner, F., Spöttl, G., Olesen, K., \& Clematide, B. (1995). Weiterbildung im Kfz-Handwerk. Eine Studie im Rahmen des Force-Programms. Luxemburg: Amt für Amtliche Veröff. der Europ. Gemeinschaften.

41. Rauner, F., \& Spöttl, G. (1995). Entwicklung eines europäischen Berufsbildes "Kfz-Mechatroniker" für die berufliche Erstausbildung unter dem Aspekt der arbeits-prozeßorientierten Strukturierung der Lehr-Inhalte. FORCE NL/93B/1/3070/P-FPC. Bremen: ITB.

42. Rauner, F., Hitz, H., Spöttl, G., \& Becker, M. (2002). Abschlussbericht Aufgabenanalyse für die Neuordnung der Berufe im Kfz-Sektor. Bremen: Universität.

43. Rollberg, R. (2001). Integrierte Unternehmensplanung. Wiesbaden: Deutscher Universitätsverlag.

44. Rührmair, C. (2014). Werkstattausrïstung: AufE-Autos vorbereitet sein. Ober-pfaffenhofen: Crain Communications GmbH. Retrieved December 29, 2014, from http://www. automobilwoche.de/apps/pbcs.dll/article?AID=/20140311/ HEFTARCHIV/140319978/1 279/werkstattausrustung-auf-e-autos-vorbereitet-sein

45. SAČR. (2015). Partneri SAČR. Turnov: SAČR. Retrieved January 19, 2015, from http:// www.sacr.cz/index.php?show=partneri

46. Schade, W., Zanker, C., Kühn, A., \& Hettesheimer, T. (2014). Sieben Herausforderungen für die deutsche Automobilindustrie. Strategische Antworten im Spannungsfeld von Globalisierung, Produkt- und Dienstleistungsinnovationen bis 2030. Berlin: Edition Sigma.

47. Simon, H. (2003). Integrative Strategie. Campus Management, 277-281. Frankfurt am Main: Campus-Verlag.

48. Syha, J. (2013). Workshop zur Umsetzung des KMK - Rahmenlehrplans „Kfz-Mechatroniker/in”. Die neue Ausbildungsverordnung Betrieblicher Ausbildungs-rahmenplan und Prüfungsanforderungen. Bonn: ZDK. Retrieved November 29, 2014, from http://www.berufsbildung.schulministerium. nrw.de/cms/upload/fahrzeugtechnik1/tagung_kfz-mechatroniker/kfz_ao_2013_zdk.pdf 
49. Scheimann, T. (2011). Produktlebenszyklen - Immer schneller neuer. Berlin: Tagesspiegel Online. Retrieved December 29, 2014, from http://www.tagesspiegel.de/wirtschaft/ produktlebenszyklen-immer-schneller-neuer/4041756.html

50. Schmutzler, C. (2012). Hardwaregestützte Energieoptimierung von Elektrik/ ElektronikArchitekturen durch adaptive Abschaltung von verteilten, eingebetteten Systemen. Karlsruhe: Kit Scientific Publication.

51. Schweikle, R. (2009). Innovationsstrategien japanischer und deutscher Unternehmen. Wiesbaden: Springer Fachmedien.

52. VDA. (2013). Jahresbericht 2013. Berlin: Verband der Automobilindustrie e. V.

53. Weimer, S. (2006). Strukturwandel im Kfz-Gewerbe: eine Branche verändert ibr Gesicht. Auswirkungen für Unternehmen und Beschäftigte. Düsseldorf: ISF München. Retrieved November 30, 2014, from http://www.isf-muenchen.de/pdf/Weimer_StrukturwandelKfz Gewerbe.pdf

54. Wenz, K. (2014). BMW: Information und Diagnose für Freie Werkstätten - Online Service System (OSS) für den freien Aftermarket. Würzburg: Vogel Business Media. Retrieved December 29, 2014, from http://www.kfz-betrieb.vogel.de/spezial/bmwspezial/articles/460807/

55. WOMACK, J.P., Jones D.T., \& Roos, D. (1991). The machine that changed the world. How Japan's secret weapon in the global auto wars will revolutionize western industry. New York: HarperPerennial.

56. ZDK. (2011). Zablen \& Fakten 2010. Bonn: Wirtschaftsgesellschaft des Kraftfahrzeuggewerbes $\mathrm{mbH}$.

57. ZDK. (2014a). Zablen \& Fakten 2013. Bonn: Wirtschaftsgesellschaft des Kraftfahrzeuggewerbes $\mathrm{mbH}$.

58. ZDK. (2014b). Interview. 22.09.2014.

59. ZDK. (2015). Kfz-Gewerbe 2014: Mehr Umsatz, mit Fahrzeugen, weniger Service. Bonn: Wirtschaftsgesellschaft des Kraftfahrzeuggewerbes mbH. Retrieved February 28, 2015, from https://www.kfzgewerbe.de/presse/aktuelle-meldungen/ pressemeldungen/kfzgewerbe-2014-mehr-umsatz-mit-fahrzeugen-weniger-service.html

60. ZEW. (2012). Ergebnisse der deutschen Innovationserhebung 2011. Fahrzeugbau. ZEW-Branchenreport Innovationen, 19 (10). Mannheim: Zentrum für Europäische Wirschaftsforschung GmbH.

61. ZEW. (2013). Ergebnisse der deutschen Innovationserhebung 2012. Fahrzeugbau. ZEW-Branchenreport Innovationen, 20 (10). Mannheim: Zentrum für Europäische Wirschaftsforschung GmbH.

62. ZEW. (2014). Ergebnisse der deutschen Innovationserhebung 2013. Fahrzeugbau. ZEW-Branchenreport Innovationen, 21 (10). Mannheim: Zentrum für Europäische Wirschaftsforschung GmbH.

63. ZVEI. (2013). Mikroelektronik - Trendanalyse bis 2017. Vorstellung lang fristiger Trends 2007 - 2012 - 2017. Frankfurt am Main: Zentralverband Elektrotechnik- und Elektronikindustrie e. V.

64. ZVEI. (2014a). Mikroelektronik - Trendanalyse bis 2018. Vorstellung langfristiger Trends 2008 - 2013 - 2018. Frankfurt am Main: Zentralverband Elektrotechnik- und Elektronikindustrie e. V. 
65. ZVEI. (2014b). Interviews. 30.09.2014 \& 06.10.2014.

\section{Contact information}

Dipl. Ing. (FH) Karl Werdich, $M B A$

Comenius University in Bratislava, Faculty of Management

Odbojárov 10, 82005 Bratislava 25, Slovak. Republic

Email:karl.werdich@gmail.com 